\title{
Evaluating Knowledge and Behavior of Bani Suaif Residents towards Visiting Tourist Sites
}

\author{
Rwan Bashir Sidky \\ Faculty of Tourism and Hotels \\ Wafaa Ahmed Elias \\ Professor Tourism Studies Department \\ Faculty of Tourism and Hotels \\ Minia University \\ Hend Mohammed \\ Assistant Professor, Tourist Guidance Department \\ Faculty of Tourism and Hotels \\ Minia University
}

Abstract

This paper aims to identify and measure Knowledge of local residents about tourist sites in Bani Suaif Governorate, as well as their behavior towards visiting these sites. To achieve that, this research employed a method of the descriptive-analytical methodology by using a questionnaire tool. The results of the questionnaire were analyzed using descriptive statistics with the support of SPSS20.0. Questionnaire-based on a quantitative approach was distributed among a random sample of Bani Suaif residents The questionnaire was handled to 300 people. Out of this number, 290 forms were available for analysis representing a (96.6\%) response rate. It was found that residents' knowledge about the tourist attractions in Bani Suaif is generally weak. Furthermore most of residents of the tested Governorate is not used to visit the tourist site in their Governorates.

Bani Suaif residents' knowledge about tourist sites needs to be improved and the trips need to be encouraged, as well as several challenges that have to be solved. Attention must be drawn to the role of the media, whether read, audio or visual. social media has to be used widely. 
Key words: Bani Suaif, Domestic Tourism, Knowledge, Tourist Behavior, Tourist Destination,

\section{Introduction}

Tourism is defined as the temporary movement of individuals to destinations away from their normal place of work and residence, including the activities carried out during their stay in a targeted destination and the facilities created to meet their desires and needs (Ghanem, 2017). Tourist knowledge indicates tourists' understanding of related knowledge about travel. For the tourists, declarative knowledge represents their perception of the travel, while procedural knowledge represents how they practically use the knowledge from planning for the trip, starting the trip, to the end of the trip (Tsaur, 2010).

Behavior is the manner an individual acts towards people, society or things. It can be either good or bad. Based on the social norms, it can be normal or abnormal. Society will always try to modify bad behavior and attempt to bring abnormal behavior back to normal. Therefore, "Behavior can be defined as the way an individual conducts by himself or herself' (Allen, 2000, p.9).

The tourist behavior is a collective term of pre-visit's decision making before initiating a visit, evaluations, experience onsite or during visits and behavioral actions done post-visits (Kempiak, 2017). Moreover, visitors' behavior can be considered in terms of length of stay, type of accommodation, mode of transportation, activities they are engaged in, travel budget and expenditure, and so forth (Disegna, 2016).

This research aims to assess the local residents' knowledge and behavior towards visiting tourist sites and the challenges faced by them during visits Moreover, the research provides some recommendations to overcome any obstacles may meet during their visits. It also provides suggestions to encourage residents to visit these sites. 


\section{Literature Review}

Knowledge

Knowledge is used in everyday linguistic communication all the time. Sometimes mean by knowledge to know-how, even use it to refer to information. Knowledge "is the information associated with experience, context, interpretation, reflection, intuition, and creativity. Part of the issue of getting a definition to knowledge emerges from its human relationship to two other concepts, namely "data and information". These two terms are often regarded as lower denominations of knowledge (Karagözoğlu, 2017, p.3).

\section{Tourist Behavior}

Tourist behavior is one of the most researched areas of tourism. It is the consumption of both every day and unusual products and services outside of the environment of everyday life (Juvan et al., 2017).

The Factors that influence of Visitor behavior

Visitor's behaviors are affected by numerous An image of destination and evaluative elements such as quality of the trip, perceived value and satisfaction directly affect visitor's behavior (Teo et al., 2014). Chen and Tsai (2007) found that destination image appears to have the most vital effects on tourist behavioral intentions such as intention to revisit and willingness to recommend, both directly and indirectly.

\section{Relationship between Attitude and Behavior}

Almost everybody has an intuitive understanding of behavior and attitude. "Attitude" may indicate how a person might behave in a specific situation (Moktan, 2017). They highlighted that "tourist behavior" is a collective term of pre visit's decision making, onsite experience, experience evaluations and post-visits behavioral intentions and behaviors (Kempiak, 2017). Furthermore, visitors' behavior can be considered in terms of duration of stay, type of accommodation, mode of transportation, activities they are participating, travel budget and rate of expenditure, and so forth (Disegna, 2016). It can be said that attitudes are determining factors of behavioral intentions. 


\section{Domestic Tourism}

Domestic tourism as the travel by residents of a country within the country, which can be the same day or overnight within or outside the same territory but excluding traveling for work or school. Domestic tourism is described as "any person residing in a country who travels to a place within the country, outside his/her usual environment for a period not exceeding 12 months" (UNWTO, 2008).

\section{The importance of domestic tourism}

The importance of domestic tourism can be represented in several aspects, and the most important ones are: increasing residents awareness of the tourism importance to their country, including stunning natural attraction locations, historical and ancient monuments, and heritage sites, in order to deepen the national identity belonging, expand and increase the local communities interaction with the tourism attraction constituents, and locations. This will be followed by directing the attention and caring about the tourism environment characteristics and maintaining the cleanliness and the maintenance of the tourism sites (Al-Darwesh, 2017).

\section{Bani Suaif Governorate}

Bani Suaif is one of the oldest Egyptian cities in the Nile Valley, which played a leading role in ancient Egyptian civilization. Bani Suaif is part of the north Upper Egypt governorates (Fayoum, Bani Suaif, Minia). What makes it special is that it enjoys a central location between the northern and southern parts of Egypt. According to preliminary results of the 2018 census, the population is 3.249 million (Capmas, 2019).

Beni Suaif Governorate has several attractions, thes attractions are classified into natural attraction and Man-made ones, Bani Suaif governorate is considered a museum of different eras where it hosts a lot of Egypt's treasures. It includes the second oldest step pyramid "Meidum", Dchach , 
Abu Sir Malaq and Ehnasia city ranking as Egypt's most important ancient cities in addition to the Coptic and Islamic monuments including El Sayeda Horreya Graveyard - Tomb of Marwan Ibn Mohamad, the last ruler of the Umayyad Caliphate - Beni sueif museum- and the Virgin Mary Monastery (Bani Suaif Governorate, 2017 and GOPP, 2017).

\section{Methodology}

The purpose of the fieldwork is to measure awareness of local residents about having tourist attractions in Northern Upper Egypt governorates and know their behavior towards their visits. Furthermore, the study tried to explore obstacles and challenges may face local residents in Bani Suaif. To achieve the aim of the study, quantitative approach was adopted. The quantitative approach based on a questionnaire was developed and directed to Local residents. The field study was applied in Bani Suaif Governorate; it's an important tourist destination especially for local residents because they have several important tourist attractions and archaeological sites.

The questionnaire consists of questions or statements to which individuals are asked to respond to the questions frequently asked for facts or the opinions, behavior or preferences of the respondents.

The form was designed after determining the required data according to the literature. A combination of close-ended and open-ended questions is used. The tested issues were created by the researcher and selected according to the review of the literature.

It contained 13 questions, dividing into two parts. The first part is concerning personal and field of work data i.e. age gender, income permanent place of residence. This part consists of six statements. The second part was concerned with data elated to evaluating residents visit tourist sites, the sources of their information about the tourist sites in their governorate, with whom they visit these sites, the main reason(s) of their visit, the extent and the number of their visit, and the obstacles, which they face. 


\section{The sample of the research and collecting data}

A total of 300 questionnaires were distributed among a random sample of Bani Suaif residents. Amongst the 300 forms, 290 forms were valid for analyzing with the responding rate of $96.6 . \%$, the results of this study has been organized according to the variables.

The questionnaire was analyzed by SPSS version 22 by calculating frequencies, percentages. Correlations between demographics factors and some other items of the study are also tested such as: educational level and occupation

\section{Findings and Discussion}

The following part explains the results concerning the knowledge and behavior of residents in Northern Upper Egypt towards

\section{First Part}

- Demographic Characteristics of Respondents

Demographic information in this study covers questions from 1 to 5 .

Table (1) shows the demographic characteristics of the sample in terms of their income. The percentage of females and males are approximately equal (53.1\% and 47 respectively). Youth (44.1\% are the majority), while $37.1 \%$ were less than 21 years old. A few percentages were more than 60 years $(4.8 \%)$. Educational level, $40.3 \%$ of the respondents were undergraduate, whereas $23.1 \%$ of them were postgraduate. Concerning intent of occupation, above thirty of the respondents (37\%) were employees, while $31 \%$ of the sample were students. As regards of income, about half of the respondents $(51 \%)$ earned less than 2000 EGP monthly, while $.7 \%$ earned more than 6000 EGP per month. 


\section{Table (1) Descriptive Features of respondents in Bani Suaif}

\begin{tabular}{|c|c|c|c|}
\hline \multicolumn{2}{|l|}{ Descriptive Features } & Frequency* & Percentage (\%) \\
\hline \multicolumn{4}{|l|}{ Gender } \\
\hline & Male & 136 & 50 \\
\hline & Female & 154 & 53.1 \\
\hline \multicolumn{4}{|l|}{ Age groups } \\
\hline & less than 21 & 108 & 37.2 \\
\hline & From 21 to40 & 128 & 44.1 \\
\hline & From 41 to 60 & 40 & 13.8 \\
\hline & More than 60 & 14 & 4.8 \\
\hline \multicolumn{4}{|l|}{ Educational level } \\
\hline & Secondary school & 106 & 36.6 \\
\hline & under graduate & 117 & 40.3 \\
\hline & post graduate & 67 & 23.1 \\
\hline \multicolumn{4}{|l|}{ Occupation } \\
\hline & Student & 92 & 31.7 \\
\hline & Employee & 107 & 36.9 \\
\hline & free lancer & 31 & 10.7 \\
\hline & Academic & 26 & 9.0 \\
\hline & Other & 34 & 11.7 \\
\hline \multicolumn{4}{|c|}{ Income (per month: in Egyptian pound) } \\
\hline & less than 2000 & 148 & 51.0 \\
\hline & 2001 to 4000 & 131 & 45.2 \\
\hline & 4001 to 6000 & 9 & 3.1 \\
\hline & More than 6000 & 2 & .7 \\
\hline
\end{tabular}

*The total number is 290

\section{Second Part}

- Data relating to measuring knowledge and behavior of visiting tourist sites in Bani Suaif.

This part covers the questions from 7 to 13 to measure the knowledge and behavior of residents towards visiting tourist sites in Bani Suaif. The first question asked respondents if their governorate had any tourist attractions, this question was asked for the purpose to measure awareness of residents about having attractions in Bani Suaif. The answers are presented in Table2. Most of the tested sample (94.8\%) answered that they had tourist 
sites in Bani Suaif, only 4 respondents declared that they did not know about any tourist attractions in Bani Suaif.

Table(2): The sample awareness of having attractions in Bani Suaif governorate.

\begin{tabular}{|l|c|c|c|c|c|c|}
\hline \multicolumn{1}{|c|}{ Variables } & \multicolumn{2}{|c|}{ Yes, it has } & \multicolumn{2}{|c|}{$\begin{array}{c}\text { No, it has } \\
\text { not }\end{array}$} & \multicolumn{2}{|c|}{$\begin{array}{c}\text { I don't not } \\
\text { know }\end{array}$} \\
\hline $\begin{array}{l}\text { The represented aware of } \\
\text { having tourist attractions } \\
\text { in their governorate }\end{array}$ & Freq & $\%$ & Ferq & $\%$ & Ferq & $\%$ \\
\cline { 2 - 8 } & 275 & 94.8 & 11 & 3.8 & 4 & 1.4 \\
\hline
\end{tabular}

If the answer to the previous question yes, the sample told that they could answer of the following questions:

The respondents about their source of information about the tourist attractions in Bani Suaif. The sample told that they could choose more than one answer to this question. The answers of respondents can be demonstrated from question three in table3. Nearly half of respondents knew about the tourist attractions from friends and relatives (40.7\%), followed by percentage $37.9 \%$ had their knowledge from the previous trips. Only $7.6 \%$ of the sample declared that they got their source of information through travel agencies.

Table (3) The sources of information about the tourist sites in Bani Suaif.

\begin{tabular}{|l|c|c|}
\hline \multicolumn{1}{|c|}{ Variables } & Freq. & \% \\
\hline Friends and relative & 118 & 40.7 \\
\hline a previous trip & 110 & 37.9 \\
\hline The Curriculum of School & 107 & 36.9 \\
\hline Social media & 68 & 23.4 \\
\hline T.V / Radio & 60 & 20.7 \\
\hline Books/ guides/ journals & 48 & 16.6 \\
\hline Travel agencies & 22 & 7.6 \\
\hline Tourism Applications & 9 & 3.1 \\
\hline Other & 8 & 2.8 \\
\hline
\end{tabular}


The respondents were asked if they paid a visit to any tourist site in Bani Suaif governorate. the answers can be found in table 4 . Tourist sites in Bani Suaif were visited by more than $90 \%$ of the sample, while less than $1.0 \%$ did not visit any tourist site in Bani Suaif.

Table (4) The previous visits of the tourist sites in Bani Suaif

\begin{tabular}{|l|l|l|l|l|}
\hline Variables & Yes & No \\
\hline The extent to which the sample visited the & Freq & $\%$ & Ferq & \% \\
\cline { 2 - 5 } tourist sites & 271 & 93.4 & 3 & 1.0 \\
\hline
\end{tabular}

If the answer to the previous question yes, The sample told that they could answer of the following questions:

Table (5) presents the accompanied partners of the respondents during their trips. About one-third of them (35.2\%) declared that they visited the attractions with their friends. A little less percentage of the respondents $(28.6 \%)$ stated that they visited the sites colleagues, followed by those who visited them with family or alone.

Table (5) The Partners during visiting the tourist sites in Bani Suaif

\begin{tabular}{|l|c|c|}
\hline Variables & Frequency & Percentage (\%) \\
\hline Friends & 102 & 35.2 \\
\hline $\begin{array}{l}\text { with } \\
\text { colleagues }\end{array}$ & 83 & 28.6 \\
\hline Family & 60 & 20.7 \\
\hline \hline Alone & 27 & 9.3 \\
\hline
\end{tabular}

The respondents were asked about their reasons for visiting tourist attraction in Bani Suaif. is to know the intent of respondents' behavior during visiting attractions. The sample was told that they could choose more than one answer to this question. The answers of respondents of question five can be found in table 6. Nearly half of the sample $49 \%$ of the sample declared that their reason for the visit was for School or University trips. About one-third of them (39\%) declared that they visited the attractions for acquiring Culture and learning, followed by the 
percentage of $31.4 \%$ of the tested sample pointed out that relaxation and entertainment were the only reason for their visits. Only $8 \%$ of the sample indicated that they had religious reasons.

Table (6) the main reasons for visiting tourist sites in Bani Suaif

\begin{tabular}{|l|c|c|}
\hline \multicolumn{1}{|c|}{ Variables } & Freq. & \% \\
\hline School or University trips & 141 & 48.6 \\
\hline Culture and learning & 113 & 39.0 \\
\hline Relaxation and Entertainment & 91 & 31.4 \\
\hline Trying New Experiences & 39 & 13.4 \\
\hline Visiting relatives and friends & 36 & 12.4 \\
\hline Health reasons & 34 & 11.7 \\
\hline Religious reasons & 23 & 7.9 \\
\hline Others & 5 & 1.7 \\
\hline
\end{tabular}

The respondents in question 7 were asked to declare the number of their visit to some different importance and famous tourist sites in Bani Suaif. The aim of this question is to be aware of the respondents' awareness and behavior during their visits. Their answers are clarified in the next table (Table17) .Their answers showed that the most visited sites were Pyramid Meidum, El Sayeda Horreya graveyard, and Beni sueif museum. In contrast, the less visited sites were Ehnasia city, and the monastery of the virgin Merry. With regard to the information the respondent had about these sites, it could be clear that no one of the respondents gave more than one right sentence about the most-visited tourist sites : Pyramid Meidum, Snour Cave, and Beni sueif museum. This emphasizes the lack of awareness and the knowledge of residents about the famous attractions of Bani Suaif. 


\section{Table (7) The extent and the number of visits in Bani Suaif}

\begin{tabular}{|c|c|c|c|c|c|c|}
\hline \multirow[b]{2}{*}{ No. } & \multirow[t]{2}{*}{$\begin{array}{l}\text { a) The visit to } \\
\text { Bani Suaif } \\
\text { tourist site }\end{array}$} & \multicolumn{4}{|c|}{ b) The extent and the number of visits } & \multirow{2}{*}{$\begin{array}{l}\text { c) Number of } \\
\text { the written } \\
\text { information } \\
\text { about the } \\
\text { sites* }\end{array}$} \\
\hline & & $\begin{array}{c}\text { No } \\
\text { previous } \\
\text { visit }\end{array}$ & $\begin{array}{l}\text { One } \\
\text { visit }\end{array}$ & $\begin{array}{l}\text { Two } \\
\text { visits }\end{array}$ & $\begin{array}{c}\text { More } \\
\text { than two }\end{array}$ & \\
\hline 1 & $\begin{array}{l}\text { Pyramid } \\
\text { Meidum }\end{array}$ & 0 & 90 & 10 & 35 & 10 \\
\hline 2 & $\begin{array}{l}\text { EI Sayeda } \\
\text { Horreya } \\
\text { graveyard }\end{array}$ & 8 & 70 & 15 & 30 & 0 \\
\hline 3 & Snour Cave & 5 & 30 & 15 & 10 & 20 \\
\hline 4 & $\begin{array}{l}\text { Beni sueif } \\
\text { museum }\end{array}$ & 5 & 30 & 10 & 0 & 3 \\
\hline 5 & Ehnasia city & 0 & 15 & 5 & 0 & 0 \\
\hline 6 & $\begin{array}{l}\text { the monastery } \\
\text { of the virgin } \\
\text { Merry }\end{array}$ & 7 & 10 & 3 & 5 & 0 \\
\hline 7 & Beni Suaif Zoo & 0 & 7 & 3 & 5 & 0 \\
\hline 8 & $\begin{array}{l}\text { St. George } \\
\text { Church }\end{array}$ & 8 & 5 & 2 & 0 & 0 \\
\hline 9 & $\begin{array}{l}\text { Antonios } \\
\text { Monastery }\end{array}$ & 3 & 0 & 2 & 5 & 0 \\
\hline
\end{tabular}

* The number of the written pieces of information: 33

The respondents' was asked to indicate the most difficulties they faced during their visits. Their answers are clarified in the next table (number8) Transportation is a serious problem (46.6\%), whereas $24.8 \%$ of the sample clarified that difficulties facing them during their visits were the Price of Entrance Fees, followed by the lack of availability of facilities, and the quality of the accommodation (18.6\% and $17 \%$ respectively). Only $8.9 \%$ of the sample declared that they faced difficulties concerning (Safety and security). 
Table (8) The most obstacles faced by residents during their visits to Bani Suaif

\begin{tabular}{|l|c|c|}
\hline \multicolumn{1}{|c|}{ Variables } & Freq. & \% \\
\hline Transportation services & 135 & 46.6 \\
\hline Price of Entrance Fees & 72 & 24.8 \\
\hline Availability of Facilities & 54 & 18.6 \\
\hline The Quality of the Accommodation & 49 & 17 \\
\hline Overall cleanliness & 37 & 12.8 \\
\hline Safety and security & 24 & 8.3 \\
\hline Others & 0 & 0 \\
\hline
\end{tabular}

\section{Conclusion and Recommendation}

This paper takes a closer look to identify and measure awareness of local residents about having tourist sites in Bani Suaif governorate. To achieve that, this research employed a method of the qualitative methodology by using a questionnaire tool. The conclusion was extracted and several recommendations were suggested.

- The study revealed that the source of information of the local people in Bani Suaif Governorate about tourist attractions are through the curricula the study, school trips and some of their social relationships through relatives and friends.

- It turned out that poor awareness through the media (TV and radio) and social media. In addition to electronic tourism applications is a major reason for the lack of awareness of the local population.

- Most of the people who visited the monuments were accompanied by their families or colleagues.

- The study indicates that the most important reasons for visiting these attractions are school trips and acquiring culture and learning

- The study clarified that local residents declared that they face alot of serious problems during visits like transportation, the price of entrance fees, the lack of availability of facilities and the quality of the accommodation 


\section{Recommendations of the study}

- Sharing joint work among several ministries such as the Ministry of Tourism and Antiquities, the Ministry of Education, the Ministry of Youth and Sports, and the Egyptian Ministry of Environment, with the aim of raising awareness among the local population and providing their information about tourist attractions in their governorates and encouraging them to visit.

- Conducting awareness campaigns, by the archaeological awareness officials at schools, besides making symposiums in youth centers.

- Setting a plan of cleanliness and Strengthening the infrastructure and provide the ingredients for tourist attractions.

- Organizing tours by tourism agencies for residents to familiarize them attractions of Bani Suaif .

- Activating E-marketing of tourist attractions by establishing a special website for the local people and providing them with all the information about the tourist attractions. Attention to social media pages such as: Facebook and Twitter

- Introducing events and festivals agenda in Bani Suaif to promote this attraction by officials tour operators. 


\section{References:}

- Alavi Karagözoğlu, B. (2017), Science and Technology from Global and Historical Perspectives, Description of knowledge, Springer Publisher, p2.

- Al-Darwesh, H. (2017), The Role of Domestic Tourism in Supporting the National Economy, from the Point View of Employers" Field Study on Aqaba Economical City, Al Balqa Applied University, International Business Research; Vol. 10, No. 7 , Available at: https://pdfs.semanticscholar.org/33b2/31ef53b0f9c49bbfbc2e2fc0 9ef48eea6d2c.pdf, Accessed in ( 10 Dec, 2019).

- Allen, W. (2000), Behavior Modification, Tourist behavior, pp.9, UNESCO, Available at: http://www.unesco.org/education/mebam/module_4.pdf Accessed in (22 Nov.2018).

- Central Agency For Public Mobilization and Statistics, (CAPMAS), (2018), the population of Northern upper Egypt, Available https://www.capmas.gov.eg/Admin/Pages\%20Files/20185910563 1op.pdf, Accessed in (6 Dec 2018).

- Chen, C. and Tsai, D. (2007), How destination image and evaluative factors affect behavioral intentions? Tourism Management, Vol.28 pp. 1115 -1122, Available at: https://www.academia.edu/1799715/How_destination_image_and _evaluative factors_affect behavioral_intentions , Accessed in (10 Dec 2018).

- Disegna, M. (2016), Tourists expenditure behavior: the influence of satisfaction and the dependence of spending categories, Understanding Visitors behavior and Attitude, Vol.22, No.1, pp.5-30, Available at http://eprints.bournemouth.ac.uk/23263/1/2016Tourism\%20Econ omics_DisegnaOsti.pdf, Accessed in (12 Feb 2018).

- Electronic portal Tourism of Bani Swaif Governorate, (2017), Available at: http://www.beniswaif.gov.eg/New_Portal/Tour/default.aspx, Accessed in (9 Dec 2018).

- General Organization for Physical Planning (GOPP), (2017), Future vision and supporting projects for the development of Minia Governorate, Northern upper Egypt, Available at: 
http://gopp.gov.eg/wpcontent/uploads/2017/12/\%D8\%A7\%D9\%8 4\%D9\%85\%D9\%86\%D9\%8A\%D8\%A7-8-5-2017.pdf

Accessed in (23 Dec 2018).

- Ghanem, J.,(2017),Conceptualizing "the Tourist": A critical review of UNWTO, Definition, Universitat de Girona, Available at https://dugidoc.udg.edu/bitstream/handle/10256/14825/GhanemJoey_Treball. pdf, accessed in (28 Dec, 2019).

- Juvan, E. Omerzel, D. and Maravic, M. (2017), Tourist Behavior: An Overview of Models to Date, Management International conference Monastier di Treviso, Italy, Available at: http://www.hippocampus.si/ISBN/978-961-7023-71-8/2.pdf Accessed in (28 Dec 2018).

- Karlsen, T. and Gottschalk, P.(2004), Factors affecting knowledge transfer in IT projects. Engineering Management Journal, No.1, Vol.16, PP. 3-10, Available at:https://www.researchgate.net/profile/Jan_Karlsen2/publication/ 276095532_Factors_Affecting_Knowledge_Transfer_in_IT_Proj ects/links/58aea752a6fdcc6f03f02254/Factors-AffectingKnowledge-Transfer-in-IT Projects.pdf?origin=publication_detail ,Accessed in ( 15 Mar 2017).

- Kempiak, J. (2017), The heritage tourist: an understanding of the visitor experience at heritage attractions, Understanding Visitors behavior and Attitude, International Journal of Heritage Studies, Vol. 23, No. 4, pp. 375-392, Available at: http://uir.ulster.ac.uk/37513/1/RJHS_A_1277776.pdf , Accessed in (27 Dec 2018).

- Moktan, D. (2017), Attitudes and Behavior of Tourists Towards Extreme Sports in Nepal Case Study: Paragliding-Pokhara, Case Study: Paragliding-Pokhara, Centria University of Applied sciences, pp.34, Available at: http://www.theseus.fi/bitstream/handle/10024/127707/Final_thesi s.pdf? sequence $=1$, Accessed in (15 Dec. 2018).

- Teo, C. Khan, N. and Rahim, F. (2014), Understanding Cultural Heritage Visitor Behavior: The Case of Melaka as World Heritage City, Procedia - Social and Behavioral Sciences, Vol.130, pp.1-10, Available at: https://moscow.scihub.tw/2567/c417c7164d88fdfb0d7897d66323 4f9c/teo2014.pdf\#view=FitH, Accessed in (25 Apr 2018). 
- Tsaur, S. Yen, C. and Chen, C. (2010), Independent Tourist Knowledge and skills, Annals of Tourism Research, Vol. 37, No. 4, pp. 1035-1054, Available at: https://zero.scihub.tw/1309/3f977060bec263c83956376be117d8b 8/tsaur2010.pdf\#view=FitH , Accessed in (31 Dec 2018).

- UNWTO, (2008), "Tourism Satellite Account: Methodological Frame Work, Department of Economic and Social Affairs, Statistic Division, Madrid.

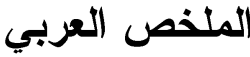

يهذف هذا البحث إلى تحديد وقياس معرفة السكان المحلين بـالمو اقع السياحية في محافظة بني سويف وسلوكهم تجاه زيارة هذه المو اقع. ولتحقيق ذللك استخدم هذا البحث المنهج الكمي التحليلي باستخدام أداة الاستبيان. تم تحليل نتائج الاستبيان باستخدام الإحصـاء الوصفي بدعم SPSS20.0. تم توزيع الاستبيان القائم على المنهج الكمي على عينة عشو ائية من سكان بني

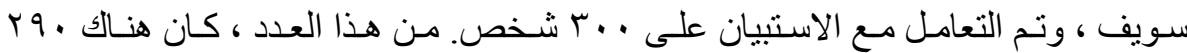
استمارة متاحة للتحليل تمثل معدل استجابة (7.79\%). . . وتوصل الباحث الي العديد من النتائج اهمها :أن معرفة السكان بالمناطق السياحية في بني سويف ضعيفة بشكل عام. علاوة على ذلك ، فإن معظم سكان المحافظة التي تم اختبار هـا لا يعتادون زيـارة المو اقع السياحية في محافظاتهم. يجب تحسين معرفة سكان بني سويف بالمو اقع السياحية وتشجيع الرحلات ، بالإضـافة إلى العديد من التحديات التي يجب حلها. يجب الانتباه إلى دور وسـائل الإعلام

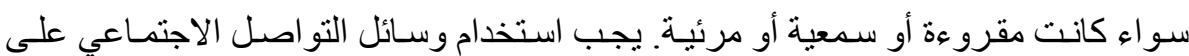

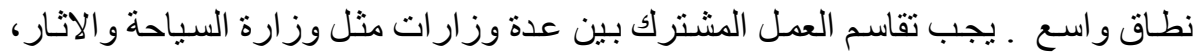
وزارة التربية والتعليم ، وزارة الثباب والرياضـة، وزارة البيئه المصرية وذلك لهدف رفع مسنوى الوعي لاى السكان المحلين وزيادة معلوماتهم حول المعالم السياحية في محافظاتهم وتثجيعهم على زيارنها. 